\title{
ПРОБЛЕМЫ ФОРМИРОВАНИЯ МЕХАНИЗМА ВНУТРЕННЕЙ ПРОДОВОЛЬСТВЕННОЙ ПОМОЩИ
}

\author{
(c) 2020 Решетникова Елена Геннадиевна \\ доктор экономических наук, профессор, \\ ведущий научный сотрудник лаборатории стратегии развития институциональной среды \\ Институт аграрных проблем Российской академии наук, Россия, Саратов \\ E-mail: elenaresh2708@mail.ru
}

Обосновывается актуальность формирования механизма внутренней продовольственной помощи как инструмента поддержания социального равновесия и государственной поддержки национальных производителей продовольствия. Дана оценка и предложены направления развития институциональной составляющей внутренней продовольственной помощи, отражены особенности её реализации на федеральном и региональном уровнях.

Ключевые слова: внутренняя продовольственная помощь, экономическая доступность продовольствия, рациональные нормы потребления.

Потребности в продовольствии относятся к числу базовых физиологических потребностей человека и лежат в основе знаменитой пирамиды мотивационной иерархии А. Маслоу [9]. В силу существующей значительной дифференциации доходов населения на межстрановом и внутринациональном уровнях в сфере потребления продовольствия наблюдается, с одной стороны, сверхпотребление, с другой - недоедание, что в обоих случаях негативно отражается на здоровье людей, может дать толчок к развитию патологических состояний. Кризисные явления в экономике, снижение реальных располагаемых доходов населения вносят существенные коррективы в реализацию закона возвышения потребностей. Происходящие при этом изменения касаются сокращения объёмов потребностей в обратной последовательности их возникновения [1]. Глобальные катаклизмы, такие как пандемия коронавируса Covid-19, ставят на повестку дня проблему удовлетворения первоочередных потребностей человека.

Мировое сообщество давно озабочено проблемой полноценного питания, разработкой путей помощи малоимущим и распространением идей здорового питания, что нашло отражение в целом ряде международных документов, таких как Декларация тысячелетия ООН или Повестка дня в области устойчивого развития на период до 2030 года.Декларация Всемирного саммита по продовольственной безопасности, принятая в Риме в 2009 году, провозгласила пять ключевых принципов в данной сфере. Третий Римский принцип нацеливает на реализацию двуединого подхода к достижению продовольственной безопасности, характеризующегося сочетанием оперативных прямых мер по продовольственной помощи наиболее уязвимым слоям населения и долгосрочных программ по сокращению и ликвидации бедности и голода [2]. Другой основополагающий международный документ в сфере организации здорового питания - Рамочная программа действий - был принят на Второй международной конференции по вопросам питания в ноябре 2014 года [10]. В нём содержалась рекомендация разработки национальных планов в области потребления продовольствия, согласования между национальными министерствами мер, направленных на обеспечение продовольственной безопасности, оздоровление рационов питания, укрепление позиций местных производителей пищевых продуктов, особенно мелких и семейных фермерских хозяйств.

Следует отметить, что внутренняя продовольственная помощь является широко используемым во многих странах инструментом сохранения социальной стабильности в обществе и государственной поддержки национальных производителей продовольствия, прежде всего, малого агробизнеса. В пункте 4 приложения II Соглашения по сельскому хозяйству ВТО отмечается, что внутренняя продовольственная помощь может быть оказана посредством прямых поставок продовольствия или предоставления средств для приобретения продовольствия по субсидируемым или рыночным ценам. Особо 
подчёркнуто, что управление данной системой является транспарентным, а закупка правительством продуктов питания производится по текущим рыночным ценам [11]. Как показывает анализ зарубежного опыта, в структуре государственной продовольственной помощи обычно присутствуют три важнейшие блока: продовольственная помощь малоимущим, школьное питание, прямые закупки у национальных производителей продовольственной продукции, прежде всего, у малых фермерских хозяйств. В разных странах получили распространение различные формы оказания внутренней продовольственной помощи. Например, в США отдаётся предпочтение программе льготной покупки продуктов, программе школьных обедов и завтраков; в странах Евросоюза действуют программы «Школьное молоко» и «Школьные фрукты», развита благотворительная деятельность в данной сфере; в Швеции создана образцовая система школьного питания, финансируемая государством; в Бразилии накоплен большой опыт по прямым закупкам школами продуктов у семейных ферм и т.д.

Вопрос о формировании механизма оказания внутренней продовольственной помощи был поставлен в нашей стране около десяти лет назад. В разделе II Доктрины продовольственной безопасности 2010 года в перечне параметров сферы потребления содержался показатель объёмов адресной продовольственной помощи, в пункте 18 раздела V говорилось о необходимости принятия решения о создании механизма адресной продовольственной помощи тем группам населения, доходы которых не дают возможность осуществления полноценного питания [4]. В Доктрине продовольственной безопасности РФ в новой редакции 2020 года в качестве рисков и угроз достижения экономической доступности продовольствия акцент делается на различиях в уровне жизни населения в городе и сельской местности, а также недостаточном развитии торговой инфраструктуры [5]. Следовало бы, на наш взгляд, дополнить перечень рисков и угроз таким моментом как значительная дифференциация населения по доходам и наличие продовольственной бедности, которые выступают в качестве объективной предпосылки формирования системы внутренней продовольственной помощи.

В Концепции внутренней продовольственной помощи, утверждённой в 2014 году, нашла отражение идея поэтапного формирования системы продовольственной помощи с учётом экономических ресурсов страны, внутренняя продовольственная помощь трактовалась как система государственной помощи населению в форме прямых поставок продуктов питания или предоставление денежных средств для приобретения продовольствия нуждающимися с учетом рациональных норм потребления [8]. Некоторые специалисты рассматривают внутреннюю продовольственную помощь, в первую очередь, как инструмент государственной поддержки национальных производителей продовольствия и определяют её как систему государственной помощи, ориентирующую население на приобретение продовольственной продукции отечественного производства и оказывающее стимулирующее воздействие на развитие национального агропродовольственного комплекса [12]. На наш взгляд, внутренняя продовольственная помощь, является комплексным понятием, в котором переплетаются меры социальной и аграрной политики.

Повышение актуальности формирования целостной системы внутренней продовольственной помощи связано со многими эндогенными и экзогенными факторами: отрицательной динамикой реальных располагаемых доходов населения, начиная с 2015 года; экономическими санкциями в отношении России, ответным продовольственным эмбарго, реализацией политики импортозамещения и новыми глобальными вызовами последнего времени. В новой редакции Доктрины продовольственной безопасности экономическая доступность продовольствия определяется как отношение фактического среднедушевого потребления основных продуктов питания к рациональным нормам, установлено пороговое значение данного параметра на уровне 100\%. Расчёты показывают, что в 2018 году этот параметр был выполнен в целом по всем домохозяйствам лишь в отношении мяса и мясных продуктов - 121,9\%, хлебных продуктов - 100\%, рыбы и рыбопродуктов - 100\% и сахара - 129,2\% [3]. В отношении других продуктов пороговое значение экономической доступности продовольствия не было достигнуто и составило: по молоку и молочным продуктам $81,8 \%$ от уровня рациональной нормы, овощам и бахчевым $-74,3 \%$, фруктам и ягодам $-74,0 \%$, картофелю - 65,6\%, яйцам - 88,8\%.Во многих доходных группах не был достигнут уровень 
рациональной нормы потребления: по мясу и мясопродуктам - у20\% населения, по рыбе и рыбопродуктам - у 50\%, по яйцам - у 80\%, по молоку и фруктам - у 90\%. Для доходной группы с самыми низкими доходами было характерно отставание фактического потребления по многим позициям не только от рациональной нормы, но и от минимальной нормы прожиточного минимума: по молоку и молочным продуктам оно составляло $60,4 \%$ от уровня минимальной нормы, по фруктам - 70,0\%, по овощам - 61,4\%, по картофелю - 52,4\%, по рыбе и рыбопродуктам - 76,8\%. Можно отметить, что для определённой части населения характерно явление продовольственной бедности, характеризующееся уровнем питания, который не соответствует даже пороговым значениям продовольственной корзины прожиточного минимума и высокой, более $50 \%$ долей расходов на питание в потребительских расходах домохозяйств. В 2018 году доля домохозяйств с расходами на питание в потребительских расходах выше 50\% по данным Росстата составила 21,6\%. Современная ситуация в продовольственной сфере свидетельствует о необходимости применения дифференцированного подхода при оценке уровня экономической доступности продовольствия. В отношении низкодоходных групп населения необходима реализация программ продовольственной помощи, в высокодоходных группах важно распространение знаний о здоровом питании, поскольку даже в этих группах структура питания далека от рациональной.

В России действует закон о социальной помощи, в соответствии с которым лицам, имеющим доход ниже прожиточного минимума, выплачивается социальное пособие для достижения его уровня. Тем не менее, существуют слои населения, потребляющие важнейшие продукты питания на уровне ниже минимальной границы прожиточного минимума, что свидетельствует о том, что прожиточный минимум как черта бедности устарел и не отражает весь спектр потребностей бедного населения. Он должен быть, по мнению многих аналитиков, увеличен в 2-3 раза, необходимо совершенствовать его структуру путём включения затрат на приобретение лекарств и освобождения по опыту многих стран бедного населения от выплаты налогов. В этом случае проблема продовольственной бедности будет решаться на основе реализации данного закона. Программы продовольственной помощи будут направлены на устранение явления продовольственной необеспеченности, то есть ситуации, когда фактическое потребление продовольствия выше минимальной, но ниже рациональной нормы потребления. Следует отметить, что на сегодняшний день оказание продовольственной помощи не унифицировано и имеет широкий спектр в регионах страны: социальные магазины, бесплатные или льготные обеды в социальных столовых, продуктовые наборы отдельным категориям граждан, реализация программы «Школьное молоко» в более 40 регионах. Минсельхозом России была подготовлена Концепция разработки мер поддержки отечественных производителей и переработчиков сельскохозяйственной продукции на основе механизмов оказания внутренней продовольственной помощи, в которой предусматривалась апробация предложенных подходов в ходе реализации в 2013-2014 гг. пилотных проектов [7]. С 2013 года в пяти субъектах Российской Федерации - Республиках Бурятия и Мордовия, Омской, Саратовской и Ульяновской областях началась реализации пилотных проектов. С этими регионами были заключены Соглашения, предусматривающие апробацию субъектами Российской Федерации за счет средств региональных бюджетов механизмов внутренней продовольственной помощи, а также методическую поддержку и мониторинг хода их проведения Минсельхозом России. В ходе реализации проектов многое было сделано в сфере организации поставок местной продукции в бюджетные учреждения: формирование закупочных кластеров, внедрение электронных торговых площадок для заключения прямых контрактов с бюджетными учреждениями социальной сферы, строительство логистических оптово - распределительных центров, реконструкция овощехранилищ, проведение ярмарок отечественных товаров. В 2014 году регионами большее внимание было уделено программам льготной покупки продуктов питания: проект «Продуктовая карта» в Ульяновской области, развитие сети магазинов социальной направленности в Республике Бурятия, проработка вопроса о ежемесячных выплатах для малоимущих граждан на универсальную электронную карту в Омской и Саратовской областях. Реализация пилотных проектов способствовала росту поставок местной продукции в социальные учреждения регионов. Однако реализация проектов выявила и болевые точки: 
различие подходов к их осуществлению на региональном уровне, ограниченность региональных бюджетов, отсутствие стимулирующих мер государственной поддержки, не были отработаны особенности реализации продуктовых карт в сельской местности.

К факторам, сдерживающим процесс формирования системы внутренней продовольственной помощи, относят: наличие большого количества нормативно - правовых актов различной ведомственной принадлежности, делегирование полномочий реализации внутренней продовольственной помощи на региональный уровень [6]. Следует отметить, что в настоящее время в общем виде определены основы институциональной составляющей внутренней продовольственной помощи, однако отсутствует единая нормативно-правовая база механизма её осуществления. Внутренняя продовольственная помощь находится на стыке социальной и аграрной политики, поэтому необходима разработка федеральной программы, в координации выполнения параметров которой принимали бы участие не только Министерство сельского хозяйства, но и Министерство труда и социальной защиты. Целесообразно отражение в Государственной программе развития сельского хозяйства, переведённой на проектное управление, вопросов оказания продовольственной помощи наиболее уязвимым слоям населения, функционирования инфраструктуры системы социального питания. Должны быть установлены на федеральном уровне единые требования к участникам программ внутренней продовольственной помощи: поставщикам, организациям торговли и социального питания, банкам - эмитентам электронных карт.

Структура внутренней продовольственной помощи, финансируемой из федерального бюджета, должна включать: программу льготной покупки продуктов по дебетовым картам в городе, на селе - там, где нет технической возможности посредством продовольственных сертификатов. Продовольственная помощь беременным и кормящим женщинам, детям до трёх лет целесообразна в форме продуктовых наборов в специальных отделах магазинов. Программа бесплатного горячего питания для школьников с первого по четвёртый классы в соответствии с задачей, поставленной в Послании Президента РФ Федеральному Собранию 15 января 2020 года, должна иметь федеральный статус. Здесь важна организация контроля качества поставляемых продовольственных товаров, в том числе путём привлечения родительских комитетов школ. При организации школьного и социального питания государство должно стимулировать заключение прямых договоров с местными производителями, в частности, малым агробизнесом. Региональный уровень системы внутренней продовольственной помощи может включать создание бесплатных столовых для малоимущих и разработку дополнительных программ, направленных на увеличение потребления тех продуктов питания, по которым в регионе наблюдается отставание от нормативного уровня.

\section{Статья подготовлена при финансовой поддержке РФФИ проекта № 19-010-00148 А.}

\section{Библиографический список}

1. Важенина И. С. Возвышение потребностей: теория и реалии //Журнал экономической теории. 2016. № 1. С. $14-23$.

2. Декларация Всемирного саммита по продовольственной безопасности. [Электронный ресурс].- Режим доступа - URL: http://base.garant.ru/2568633/?_utl_t=vk9 (дата обращения 22.04.2020)

3. Динамика потребления продуктов питания в домашних хозяйствах:[Электронный ресурс]. Режим доступа - URL: https://www.gks.ru/bgd/regl/b19_101/Main.htm (дата обращения 24.04.2020)

4. Доктрина продовольственной безопасности РФ/Утв.Указом Президента РФ от 30.01.2010 № 120. [Электронный ресурс].- Режим доступа - URL: http://base.garant.ru/12172719/(дата обращения 23.04.2020)

5. Доктрина продовольственной безопасности Российской Федерации /Утв. Указом Президента РФ от 21 января 2020 г. № 20.[Электронный ресурс].- Режим доступа - URL: http://www.garant.ru/products/ipo/prime/ doc/73338425/\#ixzz6K2oJQJLA/(дата обращения 24.04.2020)

6. Иванова В.Н., Серёгин С.Н. Внутренняя продовольственная помощь - региональный аспект реализации социального проекта // Пищевая промышленность. 2016. № 8. С. 32-35. 
7. Концепция мер поддержки отечественных производителей и переработчиков сельскохозяйственной продукции на основе механизмов внутренней продовольственной помощи в рамках «зелёной корзины» ВТО. Проект. 2013: [Электронный ресурс]. Режим доступа - URL: https://www.dairynews.ru/news/kontseptsiyarazrabotki-mer-podderzhki-otechestven.html(дата обращения 24.04.2020)

8. Концепция развития внутренней продовольственной помощи в Российской Федерации/Утв.Распоряжением Правительства РФ от 3 июля 2014 г. N 1215 - р. [Электронный ресурс].- Режим доступа - URL: http:// base.garant.ru/70689502/\#ixzz6K2rmjMlR (дата обращения 24.04.2020)

9. Маслоу А. Мотивация и личность.-СПб.: Питер, 2008. - 352 с.

10. Рамочная программа действий. Итоговый документ второй международной конференции по вопросам питания. Рим. 19-21 ноября 2014 года. [Электронный ресурс].- Режим доступа - URL: http://fi.z-pdf. ru/34yuridicheskie/31287-1-rim-19-21-noyabrya-2014-goda-itogoviy-dokument-konferencii-ramochnayaprogramma-deystviy-slov-delu-spravochna.php (дата обращения 24.04.2020)

11. Соглашение по сельскому хозяйству ВТО. [Электронный ресурс].- Режим доступа - URL: https://textarchive. ru/c-1242107-pall.html/(дата обращения 21.04.2020)

12. Шахназарян Г.Э. Программа внутренней продовольственной помощи как инструмент государственной поддержки сельхозпроизводителей.[Электронный ресурс]. - Режим доступа - URL: https://cyberleninka.ru/ article/n/programma-vnutrenney-prodovolstvennoy-pomoschi-kak-instrument-gosudarstvennoy-podderzhki-s (дата обращения 22.04.2020) 